\title{
TRACKING THE VALIDITY OF PROFESSION WAQF IN A POSITIVE LEGAL PERSPECTIVE IN INDONESIA
}

\author{
Athoillah Islamy \\ athoillahislamy@yahoo.co.id \\ Institut Agama Islam Negeri Pekalongan \\ Doni Setiadi \\ doni.setiadi05@gmail.com \\ Pascasarjana Universitas Islam Negeri Walisongo, Semarang
}

\begin{abstract}
In realizing the benefit and social justice of waqf goals, efforts to innovate the management of waqf forms in Indonesia are inevitable. This study aims to find the legality of profession waqf in the review of the Waqf Law in Indonesia on the implementation of profession waqf. This type of research is literature review. Meanwhile, the type of legal research approach in this research is normative legal research. The source of this research data in the form of a variety of literature that explains the concept of profession waqf. While the knife analysis used in this study, namely Law Number 41 of 2004, Compilation of Islamic Law (KHI) and Government Regulation Number 28 of 1977. This study concludes two big conclusions. First, profession waqf is a form of innovation of waqf instruments aimed at increasing the benefit of waqf for public benefit. Second, the existence and purpose of profession waqf is in line with positive law in Indonesia which explains that waqf aim at the general welfare by utilizing the potential and economic value of waqf.
\end{abstract}

Keywords: Profession waqf, innovation, positive law

\section{Abstrak}

Dalam mewujudkan kemaslahatan dan keadilan sosial dari tujuan wakaf, upaya inovasi pengelolaan bentuk wakaf di Indonesia menjadi hal yang tidak terelakan. Penelitian ini bertujuan untuk menemukan keabsahan hukum wakaf profesi dalam tinjauan Undang-Undang Wakaf di Indonesia terhadap implementasi wakaf profesi. Jenis penelitian ini, yakni kajian pustaka. Sementara itu, jenis pendektan penelitian hukum dalam penelitian ini, yakni penelitian hukum normatif. Adapun sumber data penelitian ini berupa berbagai literatur yang menjelaskan konsep wakaf profesi. Sedangkan pisau analisis yang digunakan dalam penelitian ini, yakni Undang-Undang Nomor 41 Tahun 2004, Kompilasi Hukum Islam (KHI) dan 
Peraturan Pemerintah Nomor 28 Tahun 1977. Penelitian ini menyimpulkan dua kesimpulan besar. Pertama, wakaf profesi merupakan bentuk inovasi instrument wakaf yang bertujuan meningkatkan kemanfaatan wakaf bagi kemaslahatan umum. Kedua, eksistensi dan tujuan dari wakaf profesi sejalan dengan hukum positif di Indonesia yang menjelaskan bahwa wakaf bertujuan mensejahterakan umum dengan manfaatkan potensi dan nilai ekonomis harta benda wakaf.

Kata kunci: Wakaf, profesi, Inovasi, hukum positif

\section{A. Introduction}

In Islamic teachings, waqf is one of the teachings that has a social dimension. Although waqf is not an obligation of every Muslim, but waqf is a social worship that contains virtue and great glory. ${ }^{1}$ This shows that waqf is different from other social services in Islam where the legal provisions are mandatory as well as the obligation of zakat.

The waqf law itself in the epsitemology of Islamic law is a law that is ijtihadi which means, that all forms of conditions, harmony, waqf law are the result of the fruit of ulama ijtihad, Ijtihad is a process of extracting Islamic law based on a rational interpretation of the theological foundation of Islamic law (al-Qur'an and Hadith) in earnest. ${ }^{2}$ and not something that has been qoth'i (certainly) the legal proposition. ${ }^{3}$ Therefore, various innovation efforts in managing waqf become very impossible as the times develop which causes the needs of dynamic and complex people. In this study, the author will look at the legitimacy of profession waqf in a positive legal perspective in Indonesia.

\section{B. Research Methods}

The type of research is literature review. Meanwhile, the type of approach to legal research in this study, namely normative legal research. The data source of this research is in the form of various literatures that explain the concept of professional endowments. While the analysis knife used in this study, namely Law Number 41 of 2004, Compilation of Islamic Law and Government Regulation Number 28 of 1977.

\footnotetext{
${ }^{1}$ Anang Rikza Masyhadi, 2007, Ragam Wakaf, Ijtihad - Ijtihad Baru dalam Wakaf Kontemporer, Tazakka Publihing, Batang, page 5.

${ }^{2}$ Zahrotul Idami, 2011, "IjtIhad and Its Influence On The Development Of State In Islam History”, Kanun Jurnal Ilmu Hukum, No. 5, page. 122

${ }^{3}$ Koran Mini Tazakka Edisi 66, Desember 2016, page. 3
} 


\section{Results and Discussion}

\section{Discourse on the Distribution of Waqf Objects : Between Ownership Rights and Utilization}

The existence of waqf is one of the instruments of social worship in Islamic teachings. In addition, waqf is also one of the economic instruments of Islam which contains various fundamental Islamic values, including benefit (maslahah), goodness (ihsān) and social solidarity (ukhuwah). ${ }^{4}$ These values are the characteristics of waqf instruments.

Through waqf instruments, muslims can distribute the benefits of their property to the wider community, namely individual benefits towards social benefits. However, in matters related to what is the object of distribution in waqf, is the benefit or not only the benefit, but also the ownership status of the object of the waqf? In this case if traced the opinions of the Imams of fiqh there are different views in defining the meaning of waqf. According to the Hanafi's Mazhab, waqf is to hold objects which according to law remain in waqif (waqf people) in order to use them for virtue. Based on this definition, the ownership of waqf property cannot be separated from the waqf, even waqif may withdraw it or sell it. Not only that, when the waqif died, the treasure became an inheritance for his heirs. ${ }^{5}$ This it can be concluded in the view of the Hanafi's Mazhab, to endow property does not mean leaving absolute ownership rights. However, in the case of exceptions, the Hanafi's Mazhab acknowledges the existence of an irrevocable waqf property, namely waqf which is carried out in a will. Not only that, waqf assets based on legal decisions cannot and cannot be withdrawn. Likewise with waqf property that has been used for the development of the mosque. ${ }^{6}$

In contrast to the Hanafi's Mazhab, according to the Maliki school of thought, endowments, namely making the results of the benefits of the property given to those entitled to it can be limited by time in accordance

${ }^{4}$ Firman Muntaqo, 2015, "Problematika dan Prospek Wakaf Produktif di Indonesia", alAhkam, Vol. 25, No. 1, page 85.

${ }^{5}$ Departemen Agama, 2007, Fiqih Wakaf, Direktorat Jenderal Bimbingan Masyrakat Islam Direktorat Pemberdayaan Wakaf: Jakarta. 2007, h.10 4.

${ }^{6}$ Suhrawardi K. Lubis, dkk, Wakaf dan Pemberdayaan Umat, Sinar Grafika, Jakarta, page 
with the wishes of waqif. ${ }^{7}$ In the view of the Maliki's Mazhab, ownership of waqf property remains in the hands of waqif. While the period of validity of waqf is not forever, but depends on the wishes of waqf in accordance with his decision. However, it does not mean that waqf may be withdrawn in the middle of the journey. This is due to the fact that waqif may not withdraw its waqf pledge before the time limit has been set. Therein lies the legal certainty, where waqf is bound by pledges made by waqif.

Furthermore, the Shafi'i's Mazhab and the Hambali's Mazhab are of the opinion that wakaf is releasing assets that are represented from wakif ownership. Therefore, the wakif may not do anything to the assets represented, such as: the treatment of the owner by means of ownership to others, either by exchange or not. Not only that, the assets that have been represented cannot be inherited by their heirs. In this case, the Shafi'ite Mazhab expressly states the ownership status of the waqf property. If the endowment is declared valid, then the ownership of the endowment property is transferred from the endowment to Allah SWT. With this understanding, the assets represented belong to the people, no longer those of those who make the donation. Then the relationship of those who endow themselves with their assets is severed. ${ }^{8}$

From the description above it can be understood that there is a difference of opinion among fiqh schools regarding the ownership status of the assets represented. Whereas those who claimed their ownership were still in the hands of waqif, namely Hanafi and Maliki. This shows that the understanding of the two schools further emphasizes the aspects of the benefit or value of the assets represented. While those who claim ownership are separated from waqf, according to the Shafi'i's and Hambali's. This shows that these two schools not only emphasize the aspects of expediency, but also aspects of the transfer of ownership status of the assets represented.

${ }^{7}$ Departemen Agama, 2007, Fiqih Wakaf, Direktorat Jenderal Bimbingan Masyrakat Islam Direktorat Pemberdayaan Wakaf, Jakarta, page 16.

${ }^{8}$ Suhrawardi K. Lubis, Wakaf dan Pemberdayaan Umat, page 5. 


\section{Classification of Waqf from Various Aspects}

In terms of who is intended for endowments, then endowments can be divided into two, as follows. First, expert waqf, ie waqf which is shown to certain people, one or more, family of the waqf or not. ${ }^{9}$ Second, waqf khairi, namely waqf that is expressly for the benefit of religion (religious) or society (general virtue). Like waqf submitted for the purposes of building mosques, schools, bridges, hospitals, orphanages and so forth. ${ }^{10}$ Substantially, this waqf is one of the aspects of how to spend (utilize) assets in the way of Allah SWT. Of course, if seen from the usefulness of its benefits, namely for religious interests, especially worship, economy, culture, health, security, and so on. it would be truly beneficial for the benefit of humanity (general), not only for limited family or relatives. ${ }^{11}$

In addition to the above division, Mundhir Qahaf has made different types of waqf. He divided the types of waqf based on the objectives, time constraints, and the use of the goods. ${ }^{12}$ Further explanation is as follows.

Based on its purpose, endowments can be divided into three. First, social waqf, namely endowments that are used for the good or interests of the community, that is if the endowments are for the public interest, as well as khairi endowments. Second, family waqf, namely the purpose of waqf to benefit the waqf, his family, his descendants, and certain people, regardless of whether rich or poor, sick or healthy, and old or young. Third, the combined waqf (musytarak), namely if the purpose of the waqf is for the public and family together.

Furthermore, based on time limits waqf can be divided into two. First,eternal waqf (Muabbad). If the waqf is in the form of goods that are of eternal nature, such as land and buildings with their land, or movable property determined by endowments as endowments and productive endowments, where as a result to be distributed according to the endowment objectives, while the remainder is for costs waqf treatment and replace the damage. Second, temporary waqf (Muaqqat). If the goods

${ }^{9}$ Radie Ramli, 2008, Mutiara Cinta Rasulullah SAW, Mizan Publika, Jakarta, page 70-71.

${ }^{10}$ Elsa Kartika Sari, 2007, Pengantar Hukum Zakat dan Wakaf, Grasindo, page 66.

${ }^{11}$ Departemen Agama, 2007, Fiqih Wakaf, Direktorat Jenderal Bimbingan Masyrakat Islam Direktorat Pemberdayaan Wakaf, Jakarta, page 17. 162.

${ }^{12}$ Muhyiddin Mas Rida, 2005, Manajemen Wakaf Produktif, Khalifa, Jakarta, page 161- 
represented are items that are easily damaged when used without giving conditions to replace damaged parts. This temporary waqf can also be caused by the wish of the waqf which gives a time limit when donating the goods.

Then based on its use, waqf can also be divided into two. First, direct endowments, namely waqf whose principal goods are used to achieve its objectives, such as mosques for prayer, schools for teaching and learning activities, hospitals for treating sick people and so on. Second, productive endowments, namely endowments whose principal goods are used for production activities and the results are given in accordance with the objectives of endowments. In this productive waqf, waqf property is only used for productive purposes, both in agriculture, industry, trade and services that benefit not directly on waqf objects. ${ }^{13}$

\section{Professional Waqf As Manifestation of Benefit Waqf}

The development of waqf in Indonesia that is currently more for the needs of ritual worship, such as places of worship and so forth. While waqf for community economic empowerment is still very little. Based on research conducted by Suhadi, out of 426 respondents, 287 (67.4\%) answered that waqf land managed was not used for productive business. Whereas the land that was productively managed (32.6\%), was used for plantations $(61.7 \%)$, rice fields $(9.4 \%)$, fish ponds $(8.25 \%)$, fields $(7.7 \%)$, etc. $(5.7 \%) .{ }^{14}$ However, the waqf implementation models that exist in the community have begun to vary, ranging from the already popular ones such as land waqf, buildings, al-Qur'an to those that have not been popular, such as stock waqf. In the case of land waqf, now it has begun to be directed towards the development of infrastructure, education sector, health services and public facilities, as is the case with leading educational institutions established and managed using land waqf, such as Al Azhar University in Egypt, Cordova University in Spain, and the Indonesian Islamic University in Yogyakarta, Indonesia. ${ }^{15}$

${ }^{13}$ Anang Rikza Masyhadi, 2017, Ragam Wakaf: Ijtihad - Ijtihad Baru dalam Fiqh Wakaf Kontemporer, Tazakka Publishing, Batang, page 5.

${ }^{14}$ Wawan Hermawan, 2014, "Politik Hukum Wakaf di Indonesia," Ta'lim, Vol. 12, No. 2 , page 159 .

${ }^{15}$ Ajeng Wahyu Puspitasari, 2017, "Optimizing Productive Land Waqf Towards Farmers Prosperity,” Journal of Indonesian Applied Economics, Vol. 6, No.1, page 105. 
Although there are various types of waqf at this time, but there are still open the emergence of new types of endowments that can realize prosperity, development, and community progress. The possibility of emerging new types of waqf is very open because waqf has no explanation in the Qur'an. But in the hadith there is an explanation of waqf even though it is explained in the form of global and general law, namely holding the principal waqf property by not selling it, giving it away, or bequeath it. In this case, Mustafa Ahmad Az-Zarqa was established based on ijtihad and qiyas where reason has an important role in it. ${ }^{16}$ This opinion is in accordance with the opinion of Mustafa Dasuki Kasbah, waqf expert from the Center of Islamic Economic Studies Shaleh Kamel, Al-Azhar University, Cairo, Egypt. According to Mustafa, in general, waqf fiqh law is ijtihadiyyah qiyasiyyah, so it is possible to make innovations in its application. ${ }^{17}$ Therefore, as part of efforts to make waqf continue to play a role and contribute to the development of society, it is necessary to raise new types of waqf determined based on ijtihad such as profession waqf.

Profession waqf is waqf in the form of expertise or profession from someone to nadzir. This waqf was indeed unknown at the time of the Prophet Muhammad as well as professional zakat was not known. According to Munzir Qohaf as quoted by Anang Rikza explained that endowments occur for the benefit of valuable property. Among the types of benefit endowments, namely endowments benefit work that comes from workers, technicians, and professionals with a variety of expertise. So, profession waqf is actually endowments of work that can produce services or services, such as builders, mechanics or vehicle mechanics, doctors, teachers or lecturers, whether done independently or through institutions and companies for benevolent purposes and do not conflict with sharia. In this case, Dasuki Kasbah also stated that the endowment of the true profession is the endowment of benefits, namely physical benefits (waqf manafi'ul abdan). ${ }^{18}$ From the description above it can be understood that the existence of profession waqf is part of new innovations in terms of developing the usefulness of waqf objects.

\footnotetext{
${ }^{16}$ Artikel BWI, “Wakaf profesi”, Fahrurozi, Rabu, 24 April 2019.

${ }^{17}$ Koran Mini Tazakka Edisi 66, Desember 2016, page 3.

${ }^{18}$ Anang Rikza Masyhadi, 2007, Ragam Wakaf, Ijtihad - Ijtihad Baru dalam Wakaf Kontemporer, Tazakka Publihing, Batang, page 21.
} 


\section{Legitimacy of Professional Endowments in Positive Law in Indonesia}

As an instrument of Islamic economics that has existed since 1400 years ago. The existence of waqf has contributed greatly to the government in terms of improving the welfare of the community. ${ }^{19}$ In the Indonesian context, one of the important factors that characterizes the style and development of waqf in Indonesia, namely when the state participates in regulating waqf policies through a set of positive laws. In this policy, the vision and direction of waqf policy is largely determined by how the ruling regime sees the potential and organization of waqf, both in terms of its interests and the interests of Muslims in general. ${ }^{20}$ Therefore, the background of the birth of the Waqf Law in Indonesia is possible to be related to political, economic, and law enforcement motives as well.

Besides intending to accommodate the interests in the religious social life of Muslims, the Indonesian government is also aware that the development of waqf institutions can improve the social welfare of Muslims. Therefore, the Ministry of Religion plays a significant role in initiating and facilitating the birth of a set of philanthropic regulations, specifically Law Number. 24 of 2004 concerning waqf. Especially related to the existence of cash waqf and productive waqf has a role in increasing the economic level of society through the provision of job vacancies. ${ }^{21}$ Therefore the existence of waqf in Indonesia both for cash waqf and productive waqf has enormous potential for the welfare of the community. This is if the potential can be actualized and empowered.

Broadly speaking, profession waqf have not yet been regulated in the Indonesian legislation. However, if we look at the aims and objectives of waqf stated in Law Article 1 (1) Number 41 of 2004, namely the act of separating property ownership so that it is used forever or within a certain period of time for general welfare, then the existence of profession waqf as a form of waqf object development cannot be contested. In addition, the purpose of profession waqf is also in accordance with the spirit carried by Law Article 43 (2) Number 41 of 2004 concerning productive waqf. In this

\footnotetext{
${ }^{19}$ N. Rohmaningtiyas, 2018, "The Significance of Waqf in Historical and Teoritical Studies," Journal of Islamic Economics Science, Vol.1, No.1, page 41.

${ }^{20}$ Bamualim S Chaider, 2006, Wakaf, Tuhan dan Agenda Kemanusiaan, CSRC UIN Syarif Hidayatullah, Jakarta, page 83.

${ }^{21}$ Siti Inayatul Faizah, Nisful Laila, Achsania Hendratmi, 2013, "Productive Waqf as One of The Problematic to Unemployment in Indonesia", ISS \& MLB, page 591-592.
} 
case, Jaih Mubarak as quoted by Khusaeri states that productive waqf is a form of transformation from natural waqf management to professional and modern waqf management in order to increase or increase the value of waqf objects for the people who need them. ${ }^{22}$

Based on this juridical basis, the existence of professional endowments is not contradictory and acceptable legal validity in the context of existing positive law. This is because profession waqf can be an alternative means of bringing prosperity and progress to society.

Not only the juridical consideration above, in Article $1 \mathrm{~b}$ Government Regulation No. 28 of 1977 it is explained that the meaning of waqf is the legal act of a person or legal entity separating assets in the form of owned land and institutionalizing it for ever for the sake of worship or public needs. Such understanding of waqf is parallel with the existence of functional profession waqf aimed at overcoming the problem of poverty and economic empowerment of the people which is a major goal of Government Regulation No. 28 of 1977.

As a guideline for Islamic family law for Indonesian society, the existence of the Compilation of Islamic Law (KHI) also regulates the implementation of waqf. ${ }^{23}$ In Book III of the Article 1 Compilation of Islamic Law (KHI) it is also explained that waqf is to separate ownership of property and institutionalize it for ever in the interests of worship or public needs. This explanation also confirms that the object of waqf instrument in Indonesia is expected to be constantly developing, therefore the existence of professional waqf is not only a product of waqf object development, but can also deliver the paradigm of Indonesian society from the old paradigm of the existence of waqf which is only consumptive to a new paradigm that is productive. ${ }^{24}$

Based on the explanation of the various positive laws above it can be understood that there is room for innovation for the Islamic community to develop waqf objects, namely in order to develop and maximize the benefits of waqf objects. Therefore, the existence of profession waqf in

${ }^{22}$ Khusaeri, 2015, "Wakaf Produktif," al-A'raf, Vol. XII, No. 1, page 90.

${ }^{23}$ Athoillah Islamy, 2019, "Eksistensi Hukum Keluarga Islam di Indonesia dalam Dinamika Politik dan Liberalisme Pemikiran Islam," al-Istinbat : Jurnal Hukum Islam, Vol. 4, No.2, page 164.

${ }^{24}$ Rozalinda, 2015, "The Economic Empowerment of the Ummah on the Basis of

Productive Waqf in West Sumatra, Indonesia”, International Journal of Nusantara Islam, Vol. 03, No. 01 , page 31 . 
various forms such as the waqf of the doctor's profession can cure illnesses, the profession of teachers or lecturers can educate their students and other professions are forms of development efforts and ways to maximize the value of great benefits to the diversity and complexity of the needs of the wider community.

\section{Conclusion}

Based on the discussion above it can be concluded that profession waqf is waqf in the form of one's expertise or profession. Profession Waqf is a new innovation in the development and ways to maximize the value of the use of waqf objects in response to the diversity and complexity of the needs of the wider community. The existence and purpose of profession waqf are in line with positive law in Indonesia which explains that endowments aim at exploiting the potential and economic value of waqf for the welfare and benefit of the wider community.

\section{References}

\section{Books}

Abu Bakar, Irfan dan Chaiders S Bamualim, 2006, Filantropi Islam dan Keadilan Sosial. CSRC UIN Jakarta, Jakarta.

Ahsanta, Kabar Tahunan Pondok Modern Tazakka, Edisi Kedua, Tazakka Publishing, Batang.

Bamualim. S Chaider, 2006, Wakaf, Tuhan dan agenda kemanusiaan, CSRC UIN Syarif Hidayatullah Jakarta, Jakarta.

Direktorat Pemberdayaan Wakaf Depag RI, 2007, "Paradigma Baru Wakaf di Indonesia.".

Direktorat Pemberdayaan Wakaf Depag RI, 2007, "Fiqih Wakaf", Jakarta.

Direktorat Pemberdayaan Wakaf Depag RI, 2007, "Perkembangan Pengelolaan Wakaf di Indonesia".

Hermawan, Wawan, 2014, "Politik Hukum Wakaf di Indonesia" Ta'lim, Vol. 12 No. 2.

Idami, Zahrotul, 2011, "IjtIhad And Its Influence On The Development Of State In Islam History,"Kanun Jurnal Ilmu Hukum, No. 5.

Inayatul, Siti Faizah, Nisful Laila, Achsania Hendratmi, 2013, "Productive Waqf As One Of The Problematic To Unemployment In Indonesia," ISS \& MLB. 
Islamy, Athoillah, 2019, "Eksistensi Hukum Keluarga Islam di Indonesia dalam Dinamika Politik dan Liberalisme Pemikiran Islam," al-Istinbat : Jurnal Hukum Islam, Vol. 4, No.2.

Kartika Sari, Elsa, 2007, Pengantar Hukum Zakat dan Wakaf, Grasindo, Jakarta.

Khusaeri, 2015, "Wakaf Produktif," al-A'raf, Vol. XII, No. 1.

Koran Mini Tazakka Edisi 66, Desember 2016.

Koran Mini Tazakka Edisi 83, September 2018.

Lubis, Suhrawardi K. dkk, 2010, Wakaf dan Pemberdayaan Umat, Sinar Grafika, Jakarta.

Masyhadi, Anang Rikza, 2007, "Ragam Wakaf, Ijtihad - Ijtihad Baru dalam Wakaf Kontemporer", Batang, Tazakka Publihing.

Masyhadi, Anang Rikza, 2017, "Wakaf Sebagai Gaya Hidup: Meneladani Para Sahabat Nabi SAW", dalam Ragam Wakaf; Ijtihad-ijtihad Baru Dalam

Fiqh Wakaf Kontemporer, Batang, Tazakka Publishing.

Mas Rida, Muhyiddin, 2005, Manajemen Wakaf Produktif, Khalifa, Jakarta.

Muntaqo, Firman, 2015, "Problematika dan Prospek Wakaf Produktif di Indonesia,"al-Ahkam, Vol.25, No.1.

Rohmaningtiyas, N, 2018, "The Significance Of Waqf In Historical And Teoritical Studies," Journal of Islamic Economics Science, Vol.1, No.1.

Rozalinda, 2015, "The Economic Empowerment of the Ummah on the Basis of Productive Waqf in West Sumatra, Indonesia," International Journal of Nusantara Islam, Vol.03 No. 01.

Wahyu, Ajeng Puspitasari, 2017, "Optimizing Productive Land Waqf Towards Farmers Prosperity," Journal of Indonesian Applied Economics, Vol.6 No.1.

\section{Rules}

Undang - Undang Nomor 41 Tahun 2004.

Peraturan Pemerintah Nomor 28 Tahun 1977.

Kompilasi Hukum Islam (KHI). 